Brazilian Journal

of Chemical

Engineering

\title{
EFFECT OF Acidithiobacillus thiooxidans-CYSTEINE INTERACTIONS ON PYRITE BIOOXIDATION BY Acidithiobacillus ferrooxidans IN THE PRESENCE OF COAL COMPOUNDS
}

\author{
Gerardo A. Caicedo Pineda ${ }^{1 *}$ and Marco A. Márquez Godoy ${ }^{2}$ \\ ${ }^{1}$ Universidad Pedagógica y Tecnológica de Colombia, Tunja, Colombia. E-mail: gerardo.caicedo@uptc.edu.co - ORCID: 0000-0003-2320-0980 \\ ${ }^{2}$ Universidad Nacional de Colombia, Sede Medellín, Medellín, Colombia. E-mail: mmarquez@unal.edu.co - ORCID: 0000-0002-7462-2430
}

(Submitted: June 28, 2018 ; Revised: September 21, 2018 ; Accepted: September 22, 2018)

\begin{abstract}
This study evaluated the biooxidation of pyrite contained in a Colombian coal $(2.38 \mathrm{~mm}$ $<$ particle size $<0.50 \mathrm{~mm})$. The variables were cysteine concentration $(0-600 \mathrm{mg} / \mathrm{L})$ and culture type (pure Acidithiobacillus ferrooxidans (ATCC 23270) and a consortium of Acidithiobacillus thiooxidans (ATCC 15494) and Acidithiobacillus ferrooxidans). Pyrite oxidation for the assays without cysteine was $31.14 \%$ after 12 days. In the presence of pure $A$. ferrooxidans, oxidation increased by $8.18 \%$ in the assays containing $60 \mathrm{mg}$ Cys $/ \mathrm{L}$. In contrast, the counterpart using the consortium exhibited a significant increase in redox potential, which improved oxidation by $28.44 \%$. Since all the assays had a similar kaolinite removal (around $31.45 \%$ ), and the experiments without cysteine did not show differences in behaviour, the $A$. thiooxidans-cysteine interactions might have been responsible for increasing $\mathrm{Fe}^{3+}$ regeneration, alleviating the toxic effect of $\mathrm{Al}^{3+}$ ion dissolution, thus improving pyrite oxidation. The consortium-cysteine-coal interactions contrasted with those proposed by other authors for A. ferrooxidans-cysteine-pure pyrite and $A$. thiooxidans-cysteine, indicating different metabolic pathways in the presence of inorganic and organic coal matrices. On the other hand, the biooxidation rate decreased for both cultures in the presence of $600 \mathrm{mg} \mathrm{Cys} / \mathrm{L}$, showing similar inhibition to that reported in the literature.

Keywords: Pyrite oxidation; Cysteine; Sulphur-rich coals; Acidithiobacillus ferrooxidans; Acidithiobacillus thiooxidans.
\end{abstract}

\section{INTRODUCTION}

Several researches have evaluated biological oxidation of pyrite for industrial applications (e.g., gold extraction, coal biodesulphurisation, bioflotation and metal recovery) because it has many economic and environmental advantages over chemical and physical options. These processes have lower operational costs, are easily designed and built, and do not require high temperatures or pressures for their operation. Additionally, they self-regenerate oxidants in the form of ferric iron (involved in pyrite oxidation) and produce no pollutant gases, and their liquid and solid wastes are easily treated and environmentally accepted
(Bozdemir et al., 1996; Klein, 1998; Aller et al., 2001; Cara et al., 2006).

One way to improve the pyrite oxidation rate is to use certain reagents with the potential to speed up the process in an environmentally safe manner. It is known that pyrite biooxidation, mediated by $A$. ferrooxidans, can be increased by adding amino acids or proteins that contain sulfhydryl groups in their structures $(-\mathrm{SH})$ (Rojas-Chapana and Tributsch, 2000, 2001; Liu et al., 2006; Wang et al., 2010). Previous studies have shown that cysteine can behave as a corrosive agent and a chemical energy carrier, improving bacterial attack and enhancing oxidation. However, this has only been proved in pure pyrite (Rojas-Chapana and Tributsch,

\footnotetext{
* Corresponding author: Gerardo A. Caicedo Pineda - E-mail: gerardo.caicedo@uptc.edu.co
} 
2000), without considering the effect of minerals or compounds that naturally accompany the sulphide.

The use of two or more sulphur-oxidizing microorganisms in consortium has also been found to improve the process; this is particularly true of A. ferrooxidans in the presence of $A$. thiooxidans. Although A. thiooxidans does not oxidize pyrite, it can reduce sulphate precipitation by generating sulphuric acid from sulphur sub-products produced from pyrite oxidation (i.e., thiosulphate), which maintains $\mathrm{pH}$ below 2 and alleviates jarosite formation. This, in turn, prevents the loss of the reactive area of pyrite (Sand et al., 2001; Pandey et al., 2005; Garcia Jr. et al., 2007; Cardona and Márquez, 2009; Caicedo and Márquez, 2010). Since $A$. thiooxidans can also oxidize cysteine (Kodama and Mori, 1968), no research has reported the occurrence of variations in processes using a consortium of the two microorganisms.

The present study evaluated the feasibility of adding cysteine to leachate solution and analysed the interactions that occurred within pyrite oxidation in the presence of coal compounds. The aim is to contribute to an understanding of possible amino acid applications in processes such as biodesulphurisation or metals leaching from carbonaceous materials. Furthermore, this work analysed the variations by using $A$. ferrooxidans alone and in consortium with $A$. thiooxidans. Chemical and mineralogical techniques were used to explain the phenomena found in all of the processes.

\section{MATERIALS AND METHODS}

\section{Coal samples}

A highly volatile bituminous coal sample was collected from "La Angostura" mine (Morales, Cauca, Colombia). The sample was ground to a particle size of between -8 and +30 Tyler mesh $(2.38 \mathrm{~mm}<$ particle size $<0.50 \mathrm{~mm}$ ). Table 1 shows the proximate

Table 1. Proximate analysis, sulphur forms and iron composition of the coal sample.

\begin{tabular}{lcl}
\hline \multicolumn{1}{c}{ Proximate analysis $^{\mathrm{a}}$} & Value & \multicolumn{1}{c}{ Method } \\
\hline Humidity (\%) & 4.6 & ASTM D 3173 \\
Ash (\%) & 27.0 & ASTM D 3174 \\
Volatile substance (\%) & 34.7 & ISO 562 \\
Fixed carbon (\%) & 33.7 & ASTM D 3172 \\
Calorific Value (Cal/g) & 5106 & ASTM D 5865 \\
\hline \multicolumn{1}{c}{ Sulphur forms (\%) } & & \\
\hline Pyritic & 4.00 & ASTM D 2492-02 \\
Sulphate & 0.79 & ASTM D 2492-02 \\
Organic & 1.48 & ASTM 4239 \\
& & and ASTM D 2492-02 \\
\hline Iron composition (\%) & & \\
\hline Pyritic & 3.50 & ASTM D 2492-02 \\
Non-Pyritic & 0.65 & ASTM E 394-09 \\
& & and ASTM D 2492-02 \\
\hline
\end{tabular}

${ }^{a}$ All values calculated on gross basis. analysis, sulphur forms and iron composition of the coal sample.

\section{Microorganisms}

Two culture types were selected: A. ferrooxidans (ATCC 23270) and a consortium of $A$. thiooxidans (ATCC 15494) and A. ferrooxidans. The microorganisms were previously adapted to the coal sample. This consisted of successive seeding, by which characteristics such as pulp density, $\mathrm{pH}$ and ferrous sulphate concentration were gradually changed to coincide with the levels used in previous studies on Colombian coals (Cardona and Márquez, 2009; Caicedo and Márquez, 2010; Caicedo et al., 2011). The inoculums were prepared in $350 \mathrm{~mL}$ flasks with a working volume of $150 \mathrm{~mL}$, containing $1 \mathrm{~g}$ of coal per $10 \mathrm{~mL}$ of leaching solution $(1: 10)$. The composition of the leaching solution was $10 \% \mathrm{v}$ of inoculum $\left(5 \times 10^{8}\right.$ cells $/ \mathrm{mL}$ by Neubauer chamber), $0.15 \mathrm{~g} / \mathrm{L}$ of $\mathrm{Fe}^{2+}$ (from $\mathrm{FeSO}_{4} .7 \mathrm{H}_{2} \mathrm{O}$ ), $1.5 \mathrm{~mL} / \mathrm{L}$ of $98 \% \mathrm{H}_{2} \mathrm{SO}_{4}$ and the basic components of $\mathrm{T} \& \mathrm{~K}$ medium (Tuovinen and Kelly, 1973), defined as: $0.50 \mathrm{~g} / \mathrm{L}$ of $\left(\mathrm{NH}_{4}\right)_{2} \mathrm{SO}_{4}, 0.50$ $\mathrm{g} / \mathrm{L}$ of $\mathrm{MgSO}_{4} \cdot 7 \mathrm{H}_{2} \mathrm{O}$, and $0.50 \mathrm{~g} / \mathrm{L}$ of $\mathrm{KH}_{2} \mathrm{PO}_{4}$. The strains were gradually adapted to different cysteine concentrations $(0.6-600 \mathrm{mg} / \mathrm{L})$ and were incubated in a shaker for 12 days at $30 \pm 1{ }^{\circ} \mathrm{C}$, using a mixing rate of $180 \pm 2 \mathrm{rpm}$. The last stage of adaptation for each concentration of this amino acid was repeated until no variations in the biodesulphurisation rate were observed between replicas (approximately four times).

\section{Pyrite oxidation processes}

The assays were prepared in $350 \mathrm{~mL}$ flasks with a working volume of $150 \mathrm{~mL}$, using the same medium composition, coal proportion and inoculum as the adaptation stage. The variables evaluated were: (i) culture type: A. ferrooxidans and consortium, and (ii) cysteine concentration $(\mathrm{mg} / \mathrm{L}): 0,0.6,6,60$ and 600 . All of the assays were incubated for 12 days under similar conditions as those used for inoculum preparation. Each one had its respective replication and abiotic control (without the presence of microorganisms).

\section{Chemical analysis}

The $\mathrm{pH}$ and redox potential (ORP) of the assays were measured using a SCHOTT Handylab pH/ORPmeter. Total and ferrous iron in solution was determined with a Thermo GENESYS UV 10 spectrophotometer, using the ASTM E 394-09 method. At the end of the experiments, sulphur forms in the coal samples were measured using the ASTM D 2492-02 method.

\section{Mineralogical analysis}

The mineralogical composition of the original and treated coal samples was established by XRD (X-ray diffraction). XRD analysis was performed 
on -200 Tyler mesh in a Rigaku Miniflex II X-ray diffractometer, using a step-by-step method, with a $5^{\circ}$ start angle, a $70^{\circ}$ stop angle, a $0.01^{\circ}$ step angle, and a counting time of $1 \mathrm{~s}$. The minerals present in the coal were quantified by XRD, using a Rietveld refinement. All simulations and calculations were carried out with the program X'Pert HighScore Plus $\mathbb{C}$, using the database PDF2.

\section{Assays without coal}

The following assays were produced in order to corroborate the coal-microorganism-cysteine interactions: (i) A. ferrooxidans grown in $\mathrm{T} \& \mathrm{~K}$ medium, (ii) $A$. ferrooxidans grown in T\&K medium with $600 \mathrm{mg}$ Cys/L added, and (iii) A. ferrooxidans grown in T\&K medium with 1:10 coal added at day 6 . Each one had its respective replication and abiotic control (without the presence of microorganisms). The assays were monitored by taking redox potential measurements. The salt composition of the T\&K medium was not modified from its original composition (Tuovinen and Kelly, 1973).

\section{Cysteine adsorption assays}

Cysteine adsorption was measured in a 1:10 coal suspension without microorganisms. The solution was composed of: $60 \mathrm{mg}$ Cys/L, $1.5 \mathrm{~mL} \mathrm{H} \mathrm{H}_{2} \mathrm{SO} 4$ (98\% $\mathrm{v}) / \mathrm{L}$ and the basic components of T\&K medium. The cysteine concentration was measured every 30 minutes by the cobalt(II) ion method (Liu et al., 2006), until no significant changes were observed.

\section{RESULTS}

\section{Pyrite oxidation process}

Figure 1 shows the behaviour of $\mathrm{pH}$. This value increased for all assays and abiotic controls on the first day of the process. The maximum $\mathrm{pH}$ (1.64) was obtained for the assays and abiotic controls containing 60 and $600 \mathrm{mg}$ Cys/L. After day 1, the $\mathrm{pH}$ value remained over 1.60 in the assays without cysteine and decreased in the assays containing this amino acid. An inverse relationship was found between the cysteine concentration and the final $\mathrm{pH}$ value, even in the abiotic controls. Additionally, the assays presented lower values than the abiotic controls, especially when using $600 \mathrm{mg}$ Cys/L. Moreover, the assays containing $A$. thiooxidans did not present significant differences from their counterparts containing pure $A$. ferrooxidans.

Unlike the $\mathrm{pH}$, the redox potential (Eh) presented differences in the assays using $A$. ferrooxidans and the consortium (Figure 2). The Eh of the assays with $A$. ferrooxidans and 0-60 $\mathrm{mg} \mathrm{Cys/L} \mathrm{(Figure} \mathrm{4a)} \mathrm{started} \mathrm{at}$ around $450 \mathrm{mV}$, decreased on day 1, and finally rose to around $550 \mathrm{mV}$ after day 3 . The assay using $600 \mathrm{mg}$
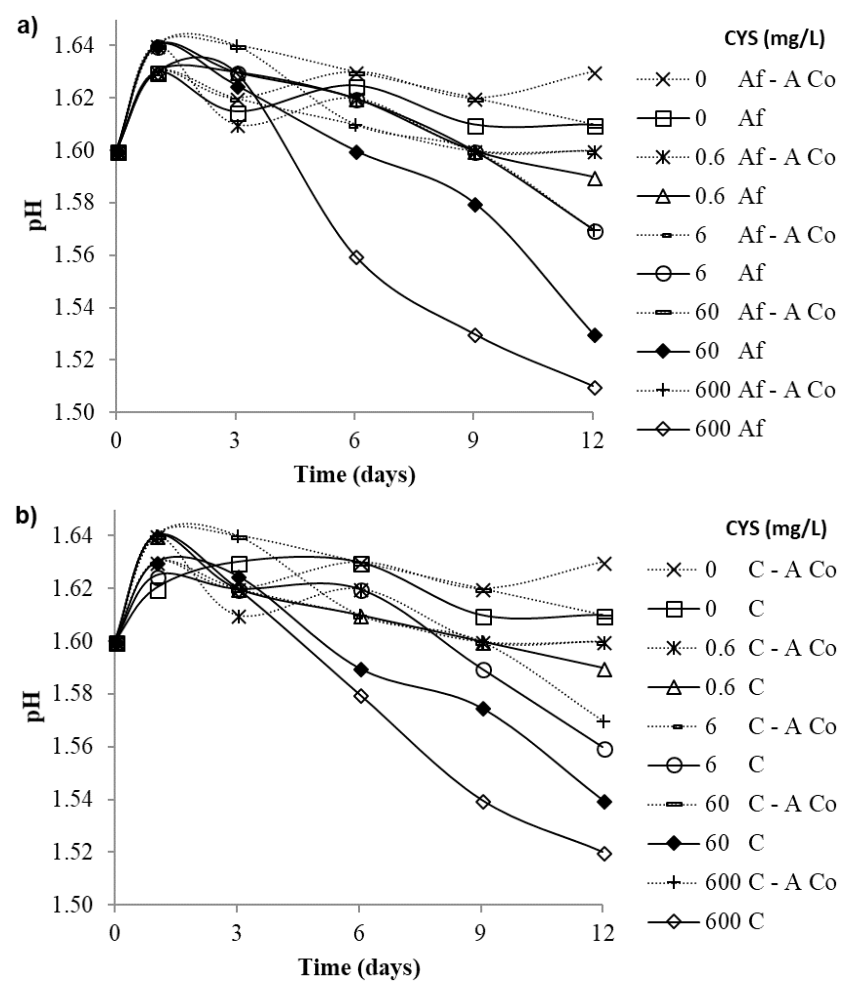

Figure 1. $\mathrm{pH}$ behaviour for all pyrite biooxidation assays at different cysteine concentrations. a) $A$. ferrooxidans (Af) and b) Consortium (C). A Co: Abiotic control.

Cys/L exhibited a different trend, with the Eh starting at a value of around $400 \mathrm{mV}$ and then stabilizing at around $500 \mathrm{mV}$ after day 3. Meanwhile, the assays using the consortium (Figure 4b) with cysteine concentrations above $6 \mathrm{mg}$ Cys/L behaved differently. The Eh increased to over $590 \mathrm{mV}$ for the assay using 60 $\mathrm{mg}$ Cys/L, reaching a maximum of $650 \mathrm{mV}$ after day 6. Meanwhile, the Eh of the assay using $600 \mathrm{mg} \mathrm{Cys} / \mathrm{L}$ remained below $480 \mathrm{mV}$ until day 3 and then rose to $650 \mathrm{mV}$ after day 9. The Eh of the abiotic controls did not significantly increase during the process.

Figure 3 shows a correlation between the Eh and the natural logarithm of the $\mathrm{Fe}^{3+} / \mathrm{Fe}^{2+}$ ratio for all of the assays. This was independent of the cysteine concentration, the bacterial culture and time. The linear trend obtained in this study indicates that $\mathrm{Fe}^{3+} /$ $\mathrm{Fe}^{2+}$ interactions can explain Eh variations with 97\% confidence.

Figure 4 presents pyrite oxidation versus cysteine concentration. Both assays without cysteine reached $31.14 \%$ oxidation, regardless of the culture type used. The assays using $A$. ferrooxidans with 0.6 and $6 \mathrm{mg}$ Cys/L did not exhibit significant variations compared to the assay without this amino acid, while pyrite oxidation only increased by $8.18 \%$ in the assay using $60 \mathrm{mg} \mathrm{Cys} / \mathrm{L}$. In contrast, oxidation significantly increased in the assays using the consortium with cysteine concentrations up to $60 \mathrm{mg} \mathrm{Cys} / \mathrm{L}$; this was 

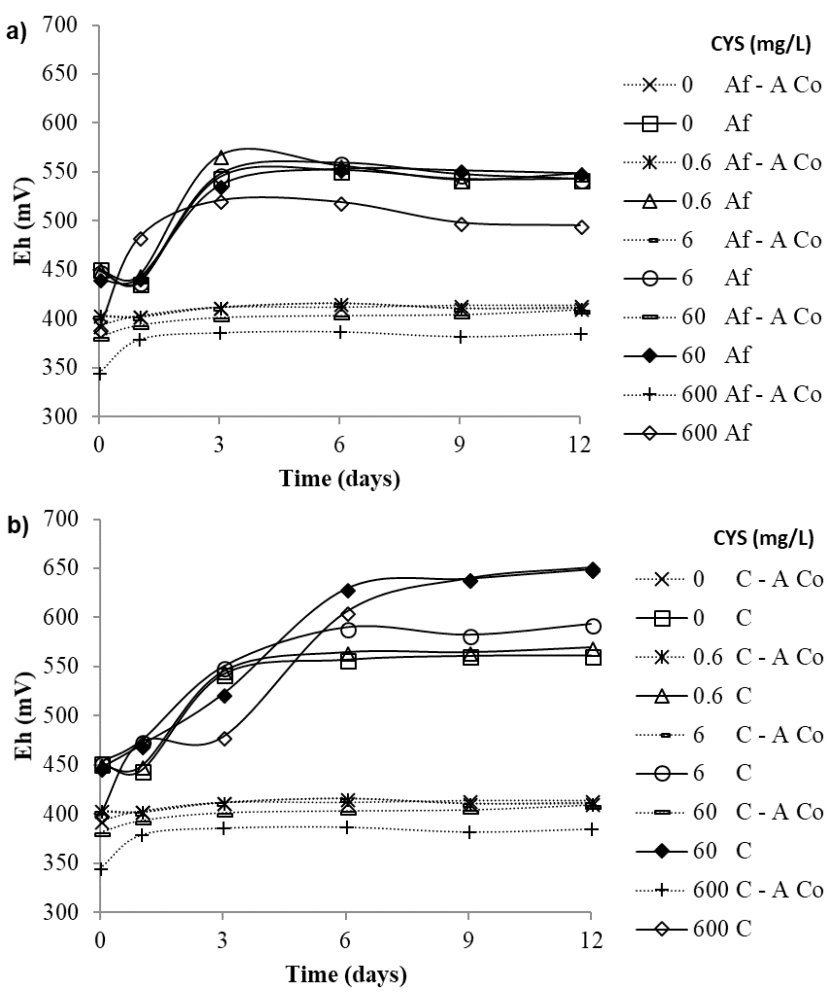

Figure 2. Redox potential behaviour for all pyrite biooxidation assays at different cysteine concentrations. a) A. ferrooxidans (Af) and b) Consortium (C). A Co: Abiotic control.

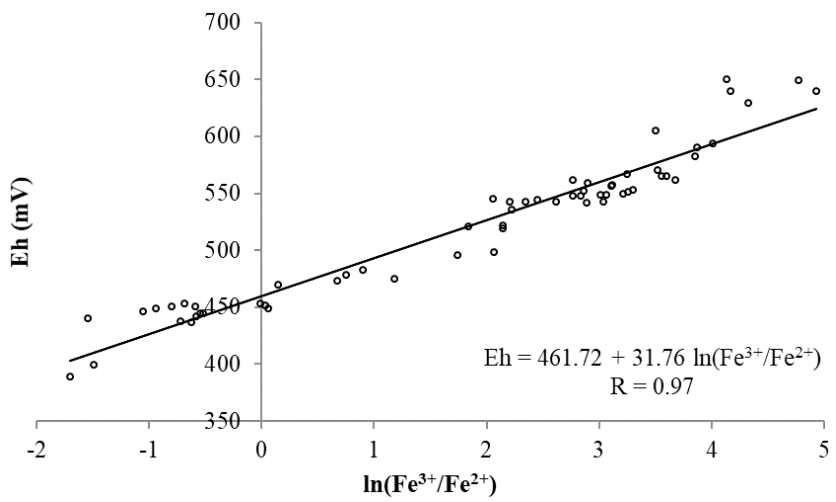

Figure 3. Eh vs. $\ln \left(\mathrm{Fe}^{3+} \mathrm{Fe}^{2+}\right)$ correlation for all pyrite biooxidation assays at different cysteine concentrations over the 12 days of the process ( $97 \%$ confidence).

the concentration at which the highest increase was observed with respect to the assay without cysteine (28.44\%). On the other hand, the use of $600 \mathrm{mg}$ Cys/L decreased pyrite oxidation to below the level obtained for the assays without this amino acid, especially for the assays containing $A$. ferrooxidans.

Figure 5 shows the percentage of iron removed. All of the assays and abiotic controls presented considerable dissolution during the first day of the process, corresponding to non-pyritic iron. However, the abiotic controls did not present significant changes after day 2. On the other hand, the assays without

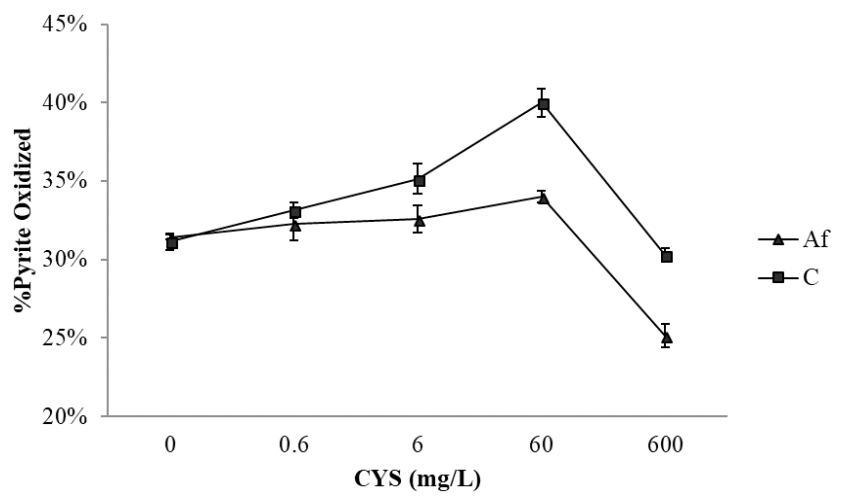

Figure 4. Percentage of pyrite biooxidation for all assays at different cysteine concentrations. Af: $A$. ferrooxidans and C: Consortium.

cysteine behaved similarly regardless of the culture used, with removal increasing until day 9, after which it tended toward a steady state. In contrast, the assays containing cysteine did not present this tendency, even after day 12. Iron removal continued to increase even in the assays with $600 \mathrm{mg} \mathrm{Cys} / \mathrm{L}$, although it was lower than in the other assays. The removal rate in the assays using cysteine was also found to depend on the culture used, as was observed with the redox potential (Figure 2 ) and pyrite oxidation behaviour (Figure 4), with the rate higher in the presence of $A$. thiooxidans. Finally, Figure 6 shows that the trend for sulphate sulphur
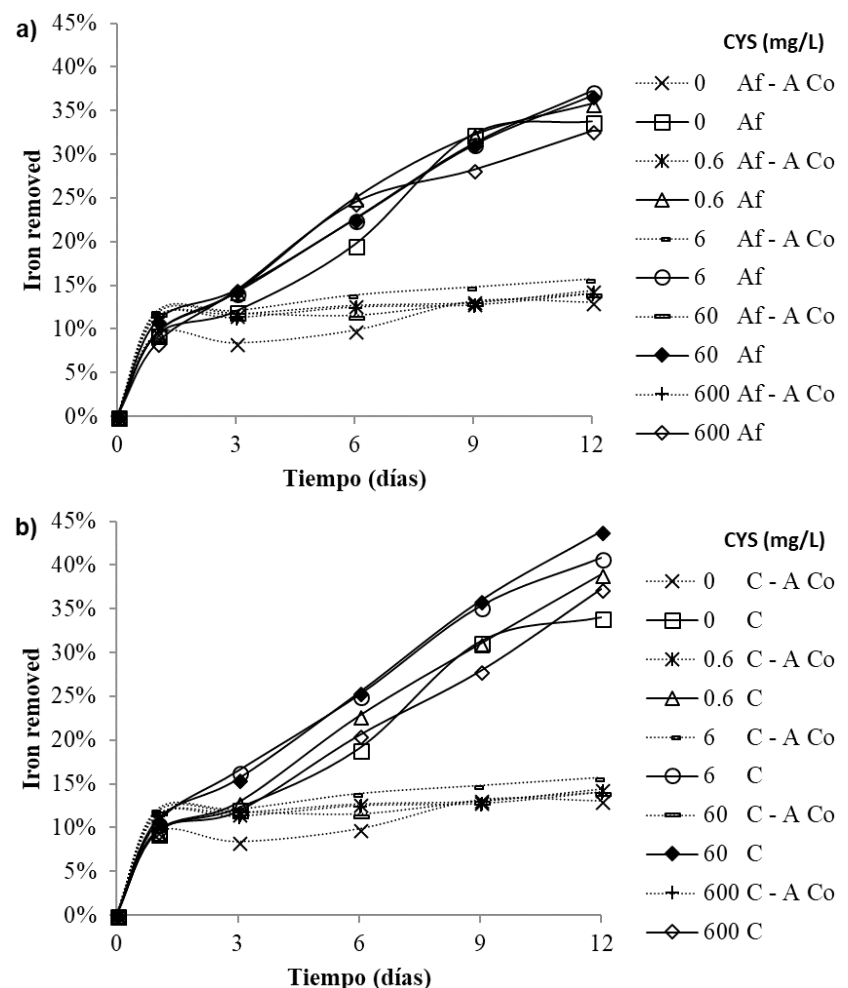

Figure 5. Iron removal behaviour for all pyrite biooxidation assays at different cysteine concentrations. a) A. ferrooxidans (Af) and b) Consortium (C). A Co: Abiotic control. 


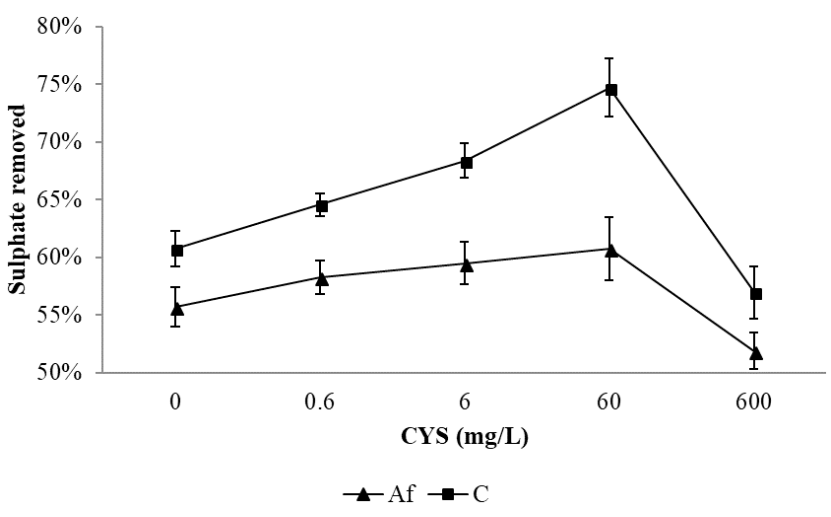

Figure 6. Percentage of sulphate removed from all pyrite biooxidation assays at different cysteine concentrations. Af: A. ferrooxidans and C: Consortium.

reduction from coal was similar to the pyrite oxidation trend for both cultures, revealing a direct dependence on the process activity.

\section{X-ray diffraction Analysis}

The X-ray diffractogram of non-treated coal (Figure 7) showed the presence of pyrite, kaolinite, quartz and jarosite. The curvature of the baseline between $2 \theta=13^{\circ}-23^{\circ}$ corresponded to the amorphous phase of coal (Lu et al., 2001). The Rietveld refinement for the semi-quantification of XRD patterns showed $7.5 \% \mathrm{w}$ of pyrite, $28.86 \% \mathrm{w}$ of kaolinite, $1.69 \% \mathrm{w}$ of quartz and an insignificant amount of jarosite (below $0.5 \%$ ). The goodness-of-fit and weighted residual profile were observed to be below $1.2 \%$ and $20 \%$, respectively, meaning that the percentages obtained with this method were acceptable (McCusker et al., 1999; Simanjuntak and Sembiring, 2011; Kniess et al., 2012).

The treated coal samples presented a decrease in kaolinite content with respect to the non-treated samples (Figure 8), with an average percentage of $18.34 \%( \pm 0.66 \%)$ found for all of the assays. There was no specific correlation between the kaolinite content and the variables evaluated. The quartz content did not present significant changes. As additional data, the jarosite content was not significant (less than $0.4 \% \mathrm{w}$ ).

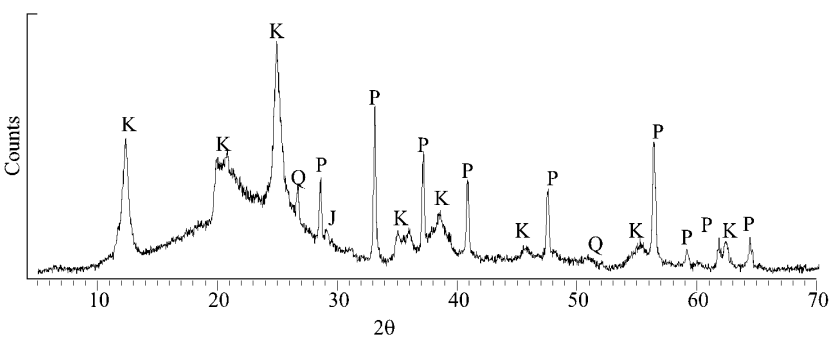

Figure 7. X-ray diffraction pattern of the coal sample before the biooxidation process. K: kaolinite, Q: quartz, P: pyrite and J: jarosite.

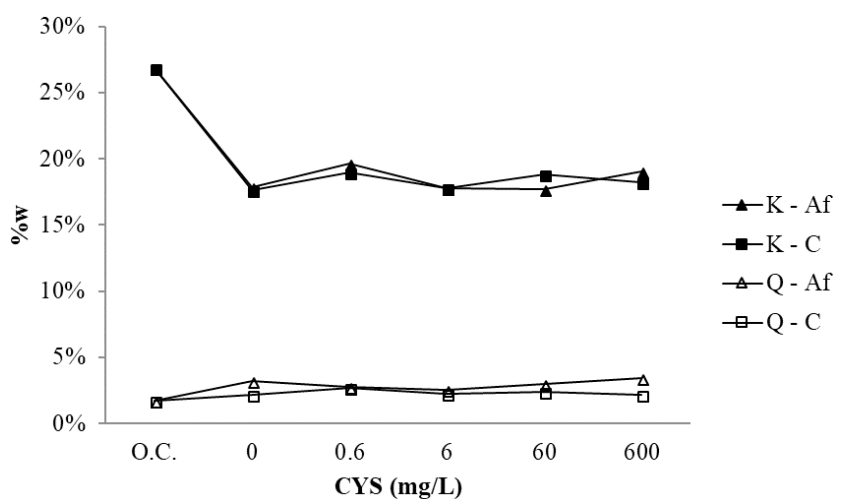

Figure 8. Silicate proportions in coal samples before and after pyrite biooxidation assays at different cysteine concentrations. Af: A. ferrooxidans, C: Consortium, K: Kaolinite, Q: Quartz and O.C.: original coal (raw).

\section{Assays without coal}

Figure 9 shows the redox potential for the assays with A. ferrooxidans grown in the original T\&K medium. The assay without cysteine surpassed $600 \mathrm{mV}$ after day 3 and rose to a maximum of $650 \mathrm{mV}$ after day 6 . After coal was added on day 6, the Eh dropped to $520 \mathrm{mV}$ and then stabilized at around $550 \mathrm{mV}$. A similar trend was seen for the assay using the pure culture without cysteine (Figure 2a). Additionally, the assays using 600 $\mathrm{mg} \mathrm{Cys} / \mathrm{L}$ of cysteine did not present $\mathrm{Fe}^{2+}$ oxidation.

\section{Cysteine adsorption assays}

Figure 10 shows the percentage of cysteine adsorbed over time, revealing that over half of the initial cysteine content disappeared from the medium after $0.5 \mathrm{~h}$. After two hours, the coal adsorbed $98 \%$ of this amino acid.

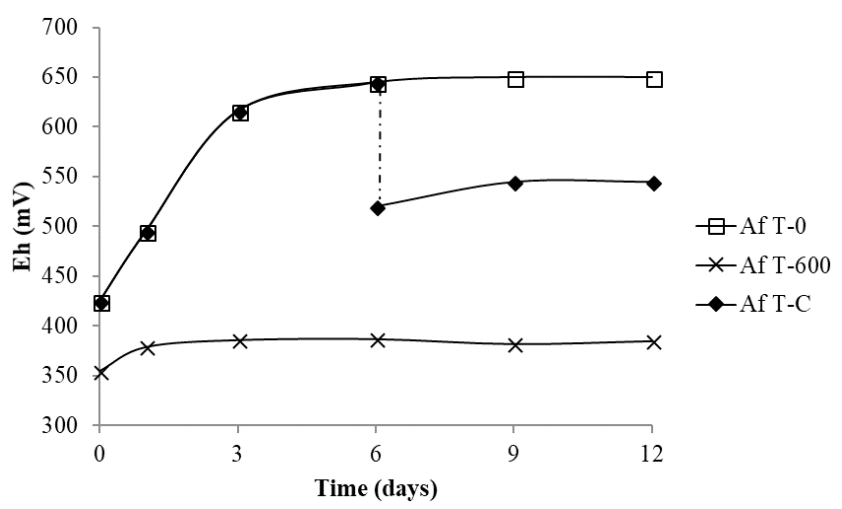

Figure 9. Redox potential behaviour vs. A. ferrooxidans growth time in $\mathrm{T} \& \mathrm{~K}$ medium. Af T-0: assay without cysteine, Af T-600: assay with $600 \mathrm{mg} \mathrm{Cys} / \mathrm{L}$ and Af T-C: Assay with coal added (1 g per $10 \mathrm{~mL}$ of leachate) after day 6 .

\section{DISCUSSION}

Cysteine concentrations of up to $60 \mathrm{mg} / \mathrm{L}$ did not have a significant effect on pyrite oxidation in the 


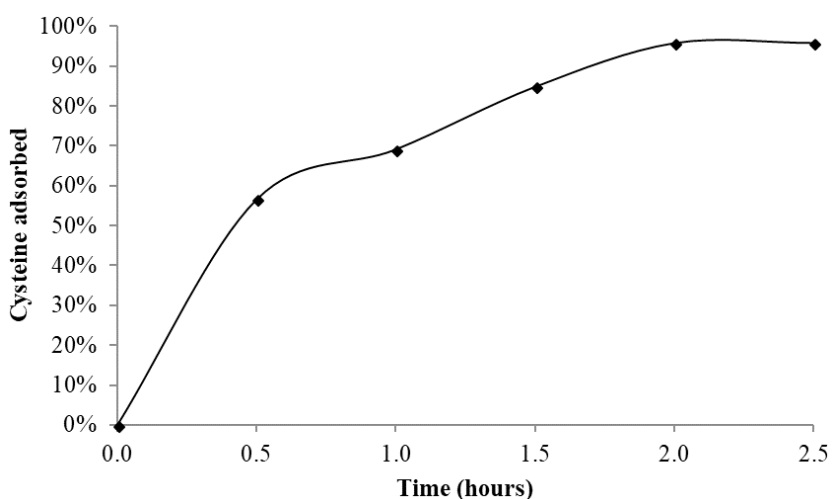

Figure 10. Percentage of cysteine adsorbed over time.

assays using $A$. ferrooxidans. This finding contrasts with previous research reported in the literature, in which this amino acid was found to double the oxidation of pure pyrite layers $(100 \mathrm{~nm})$ when using a similar strain (Rojas-Chapana and Tributsch, 2000). While it is clear that the geometry of the layers and their thickness made it possible to obtain a higher surface area, the absence of interfering material created an ideal environment where cysteine could freely interact with the pyrite-microorganism system. In contrast, pyrite had to compete with other minerals and organic matter in the biodesulphurisation process, where coal compounds played an important role.

Previous studies have found kaolinite to be a weak amino acid adsorbent (Jackson, 1970) that interacts with $-\mathrm{NH}_{3}{ }^{+}$and $-\mathrm{COOH}$ groups from cysteine through -OH groups from octahedral basal surfaces and broken hydrogen bonds (Ma and Eggleton, 1999; Benincasa et al., 2002; Lagaly et al., 2006; Petrović et al., 2012; Theng, 2012). In this study, the organic coal matrix may have also interacted with the amino acid, since bituminous coals present some adsorptive properties similar to those of activated coal (Teng, et al., 1998; Linares-Solano et al., 2000). Since the kaolinite and organic matrix proportions were higher than the pyrite proportion in the original coal sample (3.8 kaolinite: 8.4 organic matrix: 1.0 pyrite), cysteine may have preferred to bond to these compounds instead of sulphide, even beginning on the first day of the process (Figure 10).

On the other hand, the assays containing $A$. thiooxidans in consortium with $A$. ferrooxidans presented a notable increase in Eh values when using cysteine concentrations above $6 \mathrm{mg} / \mathrm{L}$ (Figure 2b), which may have enhanced pyrite oxidation (Figure 4). In regard to the information mentioned above, Eh is a key parameter for understanding the possible effect of cysteine on the biodesulphurisation process mediated by the consortium.

Figure 5 indicates that all of the Eh results had a linear trend, regardless of the assay or measurement, showing a correlation between bacterial activity and the oxidation rate of $\mathrm{Fe}^{2+}$ ions. This indicates that changes in the $\mathrm{Fe}^{3+} / \mathrm{Fe}^{2+}$ ratio can largely explain the phenomena that occurred during the process, discounting the effect of other compounds from the culture media, which may not have had a significant effect (Meruane, 2002). Taking into account the indirect mechanism of pyrite biooxidation, the chemical oxidation of sulphide by $\mathrm{Fe}^{3+}$ ions and the bioregeneration of $\mathrm{Fe}^{3+}$ ions could explain the changes in the $\mathrm{Fe}^{3+} / \mathrm{Fe}^{2+}$ ratio (Nemati et al., 1998; Sand et al., 2001), which could have directly depended on A. ferrooxidans-coal, cysteine-coal and consortium-cysteine interactions.

\section{A. ferrooxidans-coal interactions}

In general, the interactions between $A$. ferrooxidans and coal had a significant effect on $\mathrm{pH}$ and Eh values, which affected $\mathrm{Fe}^{2+}$ and pyrite oxidation. According to the literature (Nemati et al., 1998; Sand et al., 2001; Rawlings, 2005), ferrous biooxidation is proton consuming and, prior to $\mathrm{H}^{+}$production from sulphide oxidation, exceeds this consumption (this explains the $\mathrm{pH}$ increase that occurred during the initial days of the process). However, $\mathrm{Fe}^{3+}$ hydrolysis (produced by the bacteria), coupled with sulphide oxidation, increased the $\mathrm{H}^{+}$concentration after day 1 , generating a decrease in $\mathrm{pH}$ values. The considerable content of kaolinite in the coal $(28.82 \% \mathrm{w})$ may also have helped increase the $\mathrm{pH}$ value on the first day of the process. Although kaolinite presents low reactivity compared to other kinds of silicates, some researchers have reported that $\mathrm{Al}-\mathrm{OH}$ surface groups and Al-O-Si interlayer groups can generate the consumption of $\mathrm{H}^{+}$ions in an acidic medium (Ma and Eggleton, 1999). This coincides with the findings of some coal biodesulphurisation research, which has shown evidence of kaolinite dissolution from coal (Acharya et al., 2001; Malik et al., 2004; Cardona and Márquez, 2009).

Figure 9 demonstrates that coal had a negative effect on the maximum Eh value (Figure 2). Some reports in the literature have attributed this phenomenon to inorganic and organic compounds (mainly humic acids and some heavy metals) that are naturally toxic to A. ferrooxidans (Beyer et al., 1986; Ryu et al., 1993; Malik et al., 2001, 2004). Since the microorganism activity affects $\mathrm{Fe}^{3+}$ bioregeneration, the compounds in the coal sample probably reduced the $\mathrm{Fe}^{2+}$ biooxidation rate. Previous research with other Colombian coals has not shown any differences between the maximum Eh values in the presence or absence of coal, under the same conditions used in the present study (Caicedo et al., 2011; Caicedo and Márquez, 2013). However, the coals used in these studies contained less ash (5.5\%) and did not contain kaolinite (Caicedo et al., 2011).

A. ferrooxidans may also have been inhibited by the chemical dissolution of $\mathrm{Al}^{3+}$ ions, produced by the probable interaction of kaolinite with $\mathrm{H}^{+}$ions from the 
medium (Johansson et al., 1998; Malik et al., 2004; Panda et al., 2010). $\mathrm{Al}^{3+}$ ions can accumulate in the cytoplasm and cellular membrane of this bacteria, generating undesirable reactions that reduce the biomass concentration (Blight and Ralph, 2008). Previous reports have indicated that $1200 \mathrm{mg} \mathrm{Al} / \mathrm{L}$ can decrease the Eh from $622 \mathrm{mV}$ to $544 \mathrm{mV}$, while $2500 \mathrm{mg} \mathrm{Al} / \mathrm{L}$ can totally inhibit $\mathrm{Fe}^{2+}$ biooxidation (Malik et al., 2004). Due to kaolinite dissolution from the coal (Figure 8), all of the assays might have reached a maximum concentration of $1900 \mathrm{mg}$ $\mathrm{Al}^{3+} / \mathrm{L}$; nonetheless, only a partial inhibition of Eh was observed. It is possible that the $\mathrm{Al}^{3+}$ ions did not drastically affect $\mathrm{Fe}^{3+}$ bioregeneration, due to the previous adaption of the microorganism to the coal. Taking into account the indirect mechanism of sulphide oxidation, the $\mathrm{Al}^{3+}$ ions might only have affected the bacteria suspended in the culture medium, which would explain the decrease in Eh (Blake II et al., 2001; Kinzler et al., 2003; Harneit et al., 2006).

On the other hand, the significant iron removal observed in the assays and abiotic controls on the first day of the process (Figure 5) indicated the dissolution of the initial iron sulphates from the coal (Huang et al., 1994). This iron may have contributed to the process as an additional energy source to $A$. ferrooxidans (Acharya et al., 2001).

\section{Cysteine-coal interactions}

As mentioned above, the high proportion of kaolinite and organic matrix in the coal might have decreased the probability of an interaction occurring between the amino acid and the pyrite grains on the first day of the process (Figure 10). This may have been one reason why the cysteine did not significantly influence the pyrite oxidation rate in the assays using A. ferrooxidans (Figure 4); this contrasts with the efficiencies obtained by other authors for pure pyrite cultures (Rojas-Chapana and Tributsch, 2000).

The results obtained for the assay with $A$. ferrooxidans and $600 \mathrm{mg} \mathrm{Cys} / \mathrm{L}$ confirmed the possibility that cysteine was adsorbed by the coal. The Eh behaviour for this assay, with and without coal present (Figures 2 and 9), indicated that the coal helped mitigate the total inhibition of $\mathrm{Fe}^{2+}$ bioregeneration when the cysteine concentration was high (RojasChapana and Tributsch, 2000). Nonetheless, the low pyrite oxidation values obtained for the assay with 600 $\mathrm{mg}$ Cys/L showed an initial interaction between the microorganism and the amino acid in the liquid phase, which may have inhibited the bacterial population prior to coal addition. Once the coal interacted with the leachate solution, the cysteine adsorption could have mitigated some of the toxicity of the amino acid, permitting the surviving microorganisms to begin metabolizing.
Although the assays containing A. ferrooxidans and cysteine did not present great variations in the proportion of pyrite oxidation (Figure 4), a direct relationship was found between the addition of this amino acid and a decrease in $\mathrm{pH}$ (Figure 1). The corrosive properties of the-SH group likely contributed to the release of iron from the surfaces of some pyrite grains (Rojas-Chapana and Tributsch, 2000). Since $A$. ferrooxidans maintains a greater proportion of $\mathrm{Fe}^{3+}$ ions in the medium, the hydrolysis of the iron released might have generated the additional acidity. However, the adsorption of cysteine in the coal did not enable a significant decrease in $\mathrm{pH}$, since this decrease was below 0.1 units with respect to the initial value.

The additional acidification of the medium may have been linked to sulphate removal from the coal (Figure 6). Prior research has reported this relationship (Acharya et al., 2001; Cara et al., 2006; Caicedo et al., 2011), with an increase in sulphate solubility found to mitigate the re-precipitation of the pyrite oxidation byproducts. This explains why the assays using cysteine maintained a quasi-linear trend of iron removal until day 12 (Figure 5), while the iron removal rate of the assays without this amino acid decreased after day 9 . It is important to note that the assays using $600 \mathrm{mg}$ $\mathrm{Cys} / \mathrm{L}$ reached the lowest $\mathrm{pH}$ values (Figure 1 ) but also had the lowest sulphate removal (Figure 6). A parallel experiment with the original T\&K medium (Tuovinen and Kelly, 1973) and $600 \mathrm{mg}$ Cys/L indicated that this amino acid could induce sulphate re-precipitation (data not shown).

\section{Consortium-cysteine interactions}

A. thiooxidans appeared to have no influence on the $\mathrm{pH}$ value (Figure 1). This contrasted with the results reported in other studies (Salari et al., 2008; Cardona and Márquez, 2009; Caicedo and Márquez, 2010), which found that the main role of the microorganism was to produce sulphuric acid from some reduced sulphur compounds (thiosulphate, tetrathionate, monosulphides, elemental sulphur). Nonetheless, the coal and the culture medium in this study did not have any of these sulphur sources; therefore, the microorganism did not help acidify the processes.

Based on pyrite biooxidation via the thiosulphate pathway, A. thiooxidans survives in the absence of reduced-sulphur nutrients by oxidizing thiosulphate, trithionate, tetrathionate and othersulphurintermediates produced from sulphide oxidation by $A$. ferrooxidans (Sand et al., 2001). However, the chemical oxidation of these compounds in acidic media limits their availability (Schippers and Sand, 1999). Therefore, in the present study they were not sufficient to make a significant contribution via biological oxidation. For this reason, the microorganism might have found a new available energy source after cysteine addition. 
The A. thiooxidans-cysteine interactions could have produced compounds or radicals with the ability to improve redox potential, either enhancing the $\mathrm{Fe}^{3+} / \mathrm{Fe}^{2+}$ ratio or preventing the inhibition caused by kaolinite, which was not observed in the assays containing only A. ferrooxidans (Figure 4).

Microorganisms are known to have the capacity to adapt to a specific environment. They are capable of activating certain alternative enzymatic routes when the medium contains new energy sources or toxic elements (Blake II et al., 2001; Kinzler et al., 2003; Harneit et al., 2006). Previous studies have reported that $A$. thiooxidans transforms cysteine into cystine and persulphide (Kodama and Mori, 1968). Cystine does not have a positive effect on pyrite oxidation; it even causes inhibition when the cysteine concentration is above $120 \mathrm{mg} / \mathrm{L}$ (RojasChapana and Tributsch, 2000). On the other hand, persulphides (R-SS) are reactive and unstable intermediates in sulphur compound transformations, which play an important role in the formation of $\mathrm{Fe}-\mathrm{S}$ complexes and promote the consumption of sulphur nutrients and energy obtainment (Wood, 1982; RojasChapana and Tributsch, 2001; Rohwerder and Sand, 2003). Nonetheless, the role of the -SS- group in the biodesulphurisation process would only affect $A$. ferrooxidans-pyrite interactions as a chemical carrier (Wood, 1982; Rohwerder and Sand, 2003); the sulphide would be more prone to adsorbing the radical after cysteine degradation, thus preventing or breaking bonds with the rest of the coal.

Based on the A.ferrooxidans-cysteine-pyrite system proposed by Rojas-Chapana and Tributsch (2001), the hypothetical persulphide would only help stimulate the adherence of the bacteria to sulphide grains. Therefore, $\mathrm{Fe}^{2+}$ ions and pyrite oxidation would only be enhanced within the extracellular polymeric substances of the microorganism, adhered as an indirect contact mechanism (Sand et al., 2001; Sand and Gehrke, 2006). However, persulphide action cannot explain the changes in redox potential in the present study that occurred in the liquid phase when cysteine was above $6 \mathrm{mg} / \mathrm{L}$ (Figure 2). Since Eh variations were mainly seen in leaching solution (Figure 3), this indicates a different synergetic scenario for the A. thiooxidanscysteine interactions.

Taking into account the A. ferrooxidans-coal interactions, the compounds produced as a result of cysteine degradation by $A$. thiooxidans probably helped strengthen the resistance of $A$. ferrooxidans to $\mathrm{Al}^{3+}$ toxicity, thus increasing the $\mathrm{Fe}^{3+}$ ion bioregeneration rate (which explains the increase in Eh values). A recent study regarding the $A$. thiooxidans genome revealed that this bacteria naturally biosynthesized cysteine, which is used to produce proteins involved in resistance to copper (Travisany et al., 2014). Nonetheless, as of the date of the present study, there are no existing reports demonstrating that the use of amino acids or derivative products can enhance resistance to aluminium toxicity alone or in combination with microorganisms such as A. ferrooxidans.

Recent botanical research has shown a similar situation, in which some aluminium-resistant plants activate L-cysteine desulfhydrases located in different cellular compartments, such as cytosol, mitochondria and plastids, in response to the toxic attack of high concentrations of aluminium (Chen et al., 2012; $\mathrm{Fu}$ et al., 2013). This produces hydrogen sulphide $\left(\mathrm{H}_{2} \mathrm{~S}\right)$ from cysteine reservoirs in the cells. The extra support of hydrogen sulphide blocks the cell- $\mathrm{Al}^{3+}$ ion interactions, which significantly alleviates the oxidative stress caused by metal ions in acidic soils (Chen et al., 2012; Dawood et al., 2012).

The toxicity of aluminium seems to act similarly in plants and acidophilic bacteria. Both can tolerate a determined metal concentration. However, if this increases, $\mathrm{Al}^{3+}$ accumulates in the cytoplasm and cell membrane, generating undesirable reactions that affect the cell duplication mechanisms (a biomass reduction in the case of the microorganism) (Blight and Ralph, 2008; Dawood et al., 2012). Following this line of thought, in the present study, A. thiooxidans might have produced hydrogen sulphide from cysteine and A. ferrooxidans might have assimilated it to protect itself against kaolinite leaching.

The MetaCyc database shows different metabolic and enzymatic pathways of metabolism for different multicellular and unicellular organisms (Caspi et al., 2010). This database indicates that both $A$. thiooxidans and $A$. ferrooxidans, in accordance with their expected taxonomic range, can degrade cysteine via the L-cysteine desulfhydrase pathway, producing pyruvate, ammonium and hydrogen sulphide. Based on the evidence obtained in all of the experiments in this study, and the indirect mechanism of pyrite biooxidation (contact, no contact and cooperative) (Sand et al., 2001; Tributsch, 2001; Sand and Gehrke, 2006)), it is possible to formulate a scenario to explain how the L-cysteine desulfhydrase pathway could have occurred in the assays developed.

In the absence of cysteine, the culture medium (containing the microorganism) could have interacted with the coal. $\mathrm{H}^{+}$ions from the liquid phase could have leached non-pyritic iron ( $\mathrm{Fe}^{2+}$ ions) and kaolinite. As the process proceeded, A. ferrooxidans could have oxidized $\mathrm{Fe}^{2+}$ ions from the pyrite oxidation byproducts dissolved in the medium, and the $\mathrm{Fe}^{3+}$ ions generated could have initiated pyrite oxidation (RojasChapana and Tributsch, 2000; Sand et al., 2001; Sand and Gehrke, 2006). Additionally, in this scenario $A$. thiooxidans would only have obtained its energy source from the sulphur by-products (Sand et al., 2001). 
As the aluminium from kaolinite increased in the liquid phase, both bacteria could have activated L-cysteine desulfhydrases in order to protect against metal ion toxicity, thus producing hydrogen sulphide from cysteine or other thiol substances biosynthesized by the internal protein production process (RojasChapana and Tributsch, 2000; Travisany et al., 2014). However, the protection would have been affected when $\mathrm{Al}^{3+}$ surpassed $1200 \mathrm{mg} / \mathrm{L}$, thus decreasing the $\mathrm{Fe}^{2+}$ oxidation rate and reducing the chemical oxidation caused by $\mathrm{Fe}^{3+}$ ions in the liquid phase (due to the Eh decreasing from the original $650 \mathrm{mV}$ to 550 $\mathrm{mV}$, Figure 10).

When cysteine was added, the kaolinite and organic matrix of the coal could have adsorbed this amino acid and impeded its interaction with pyrite grains. Meanwhile, A. thiooxidans could have broken -SH bonds in response to the presence of aluminium toxicity, producing an excess of hydrogen sulphide via the L-cysteine desulphydration pathway. A. ferrooxidans could have interacted with the $\mathrm{H}_{2} \mathrm{~S}$ through the cell membrane, thus fortifying the preliminary protection from $\mathrm{Al}^{3+}$ toxicity, preventing growth inhibition and enhancing $\mathrm{Fe}^{3+}$ regeneration (by increasing the $\mathrm{Fe}^{3+} /$ $\mathrm{Fe}^{2+}$ ratio, Figure 3).

Although the MetaCyc database indicates that $A$. ferrooxidans can also degrade cysteine via L-cysteine desulphydrases, in the present case this microorganism probably did not carry out an intensive attack on the amino acid, because it had greater access to a basal energy source. It is possible that $A$. ferrooxidans $\mathrm{did}$ not need to take advantage of cysteine and focused instead on the main metabolic pathway $\left(\mathrm{Fe}^{2+}\right.$ biooxidation). In contrast, $A$. thiooxidans probably had a better interaction with the amino acid, since the energy source shortages limited its main pathway (reducedsulphur oxidation).

Finally, the assay using the consortium with 60 $\mathrm{mg}$ Cys/L obtained the maximum increase in pyrite oxidation. Based on the Eh behaviour (Figure 2), chemical oxidation by $\mathrm{Fe}^{3+}$ in the liquid phase was important for improving the oxidation carried out by $A$. ferrooxidans attached to pyrite grains. This indicates that a high redox potential guarantees high sulphide removal. Nonetheless, although the consortium assay using $600 \mathrm{mg}$ Cys/L reached an Eh value of around $650 \mathrm{mV}$, it had lower pyrite oxidation than the assay without cysteine.

Figure 2 shows that the assay using the consortium and $600 \mathrm{mg} C y \mathrm{~s} / \mathrm{L}$ had a delay in the lag phase during the initial days of the process. It is likely that the high concentration of cysteine inhibited A. ferrooxidans at the beginning of the process, as was observed in the assay without coal (Figure 9). The results obtained for the assay with the pure culture revealed that the coal might have adsorbed part of the cysteine, although it was not sufficient to obtain similar pyrite oxidation to the assay without cysteine (Figure 4). However, as $A$. thiooxidans degraded the cysteine, the concentration of this amino acid in the medium might have further decreased, creating an environment where $A$. ferrooxidans was disinhibited from excess amino acid and protected from aluminium. This in turn could have increased its growth and enhanced $\mathrm{Fe}^{3+}$ regeneration, as shown in Figures 2 (high redox potential) and 5 (continuous iron removal).

Based on Figure 5, the average rate of iron removal for the consortium assay using $600 \mathrm{mg} \mathrm{Cys} / \mathrm{L}$ was $130 \mathrm{mg} \mathrm{Fe} / \mathrm{L} /$ day during the last three days of the process. This increased continuously with respect to the previous days $(101.67 \mathrm{mg} / \mathrm{Fe} /$ day between days 6 and 9). This rate was higher than that of the assay using $60 \mathrm{mg} / \mathrm{L}$ (110 $\mathrm{mg} \mathrm{Fe} / \mathrm{L} /$ day), indicating that the higher concentration of cysteine might have permitted a higher pyrite oxidation rate for a longer time than the other assays. This could be because $A$. thiooxidans produced a better environment than A. ferrooxidans, the latter of which might have reached a considerable concentration in the stationary phase.

\section{CONCLUSIONS}

Coal plays an important role in the pyrite oxidation process mediated by $A$. ferrooxidans, because the interactions of this material with the liquid phase can affect the different pathways involved in the reaction mechanism. In this study, kaolinite in the coal, leached from the culture medium by the acid, was found to generate $\mathrm{Al}^{3+}$ ions. Since aluminium is toxic to the microorganism, this affected the regeneration of $\mathrm{Fe}^{3+}$ ions in solution. Additionally, the organic coal matrix acted as an amino acid adsorbent, blocking the - $\mathrm{SH}$ groups of the cysteine; this nullified the enhancing effect of the amino acid on biooxidation, as found in previous studies using pure pyrite.

When $A$. ferrooxidans acted in the presence of A. thiooxidans and $60 \mathrm{mg} / \mathrm{L}$ of cysteine, the redox potential increased to its highest level. This means that a significant improvement in $\mathrm{Fe}^{3+}$ regeneration occurred during the process. This was good because it helped increase the chemical oxidation of pyrite, creating an enhanced indirect mechanism that cooperated with $A$. ferrooxidans attached to pyrite grains. A. thiooxidans might have broken the coal-cysteine bonds and produced reagents that alleviated the toxic effects of aluminium.

The results for all of the assays indicated that the consortium-cysteine-coal interaction pathways were different from those proposed for A. ferrooxidanscysteine-pure pyrite and $A$. thiooxidans-cysteine. In order to explain how $A$. thiooxidans acted, the authors considered a hypothetical reaction mechanism based 
on the cysteine desulphydration pathway present in plants, in which L-cysteine desulfhydrases from the cells produced hydrogen sulphide, a key compound that reduces the toxic effects of aluminium. $A$. thiooxidans can hypothetically carry out this pathway, according to its expected taxonomic range. Therefore, it might have activated L-cysteine desulfhydrases in response to the unfavourable environment created within the coal biodesulphurisation processes, since the toxicity of aluminium acts similarly in plant cells as in the acidophilic microorganism. Nonetheless, a thorough study of the enzymatic pathways of the bacteria with respect to coal-cysteine interactions would be needed in order to corroborate the above hypothesis. This would help provide an understanding of how the microorganism activates certain enzymatic reactions for a specific nutrient or additive based on the particular components of the treated materials or minerals. In this case, if hydrogen sulphide was responsible for protecting $A$. ferrooxidans against aluminium, the process might have used other sources that directly supported the compound, such as sodium hydrosulphide, a known $\mathrm{H}_{2} \mathrm{~S}$ donor.

On the other hand, it is important to note that cysteine concentrations around $600 \mathrm{mg} / \mathrm{L}$ extended the lag phase of $A$. ferrooxidans, which would have affected pyrite oxidation even if $A$. thiooxidans degraded the amino acid. Nonetheless, this could have occurred in a two-stage process, in which the coal first interacted with the culture medium containing cysteine and $A$. thiooxidans alone, and, once the process showed evidence of cysteine degradation, $A$. ferrooxidans entered the system.

The advances presented in this paper are an indication of undiscovered pathways of the bacteria in response to favourable or unfavourable environments. It is important to note that the use of two or more microorganisms in an inoculum would make it possible to explore all possible reaction mechanisms occurring in the bacteria, in order to gain an understanding of how to exploit other secondary metabolites to benefit the processes.

\section{ACKNOWLEDGMENTS}

We would like to thank the Biomineralogy Laboratory (National University of Colombia), where the investigation was carried out.

\section{REFERENCES}

Acharya, C., Kar, R. N., Sukla, L. B., Bacterial removal of sulphur from three different coals, Fuel, 80, 2207-2216 (2001). https://doi.org/10.1016/ S0016-2361(01)00100-4
Aller, Á., Martínez, O., Linaje, J. A. de, Méndez, R., Morán, A., Biodesulphurisation of coal by microorganisms isolated from the coal itself, Fuel Processing Technology, 69, 45-57 (2001). https:// doi.org/10.1016/S0378-3820(00)00127-2

Benincasa, E., Brigatti, M. F., Malferrari, D., Medici, L., Poppi, L., Sorption of Cd-cysteine complexes by kaolinite, Applied Clay Science, 21, 191-201 (2002). https://doi.org/10.1016/S0169-1317(01)00100-4

Beyer, M., Ebner, H. G., Klein, J., Influence of pulp density and bioreactor design on microbial desulphurization of coal, Applied Microbiology and Biotechnology, 24, 342-346 (1986). https://doi. org/10.1007/BF00257061

Blake II, R. C., Sasaki, K., Ohmura, N., Does aporusticyanin mediate the adhesion of Thiobacillus ferrooxidans to pyrite? Hydrometallurgy, 59, 357-372 (2001). https://doi.org/10.1016/S0304386X(00)00184-5

Blight, K. R., Ralph, D. E., Aluminium sulphate and potassium nitrate effects on batch culture of iron oxidising bacteria, Hydrometallurgy, 92, 130-134 (2008). https://doi.org/10.1016/j. hydromet.2008.02.010

Bozdemir, T. Ö., Durusoy, T., Erincin, E., Yürüm, Y., Biodesulfurization of Turkish lignites, Fuel, 75, 1596-1600 (1996). https://doi.org/10.1016/00162361(96)00118-4

Caicedo, G. A., Márquez, M. A., Effect of chloride salts on biodesulfurization process of a colombian coal, Revista Facultad de Ingeniería Universidad de Antioquia, 68, 115-123 (2013).

Caicedo, G. A., Márquez, M. A., Selection procedures of consortia bacterial with $A$. ferrooxidans like bacteria and $A$. thiooxidans like bacteria in coal biodesulfurization process. Revista Facultad de Ingeniería Universidad de Antioquia, 52, 88-94 (2010).

Caicedo, G. A., Márquez, M. A., Moreno, C. X., Particle size, iron concentration and $\mathrm{pH}$ influence in biodesulfurization process of coal - laboratory tests. Revista Colombiana de Biotecnología, 13, 199-209 (2011).

Cara, J., Vargas, M., Morán, A., Gómez, E., Martínez, O., García Frutos, F. J., Biodesulphurization of a coal by packed-column leaching. Simultaneous thermogravimetric and mass spectrometric analyses, Fuel, 85, 1756-1762 (2006). https://doi. org/10.1016/j.fuel.2006.02.014

Cardona, I. C., Márquez, M. A., Biodesulfurization of two Colombian coals with native microorganisms, Fuel Processing Technology, 90, 1099-1106 (2009). https://doi.org/10.1016/j.fuproc.2009.04.022

Caspi, R., Altman, T., Dale, J. M., Dreher, K., Fulcher, C. A., Gilham, F., Kaipa, P., Karthikeyan, A. S., Kothari, A., Krummenacker, M., Latendresse, M., 
Mueller, L. A., Paley, S., Popescu, L., Pujar, A., Shearer, A. G., Zhang, P., Karp, P. D., The MetaCyc database of metabolic pathways and enzymes and the BioCyc collection of pathway/genome databases, Nucleic Acids Research, 38, D473-D479 (2010). https://doi.org/10.1093/nar/gkp875

Chen, J., Wang, W.-H., Wu, F.-H., You, C.-Y., Liu, T.W., Dong, X.-J., He, J.-X., Zheng, H.-L., Hydrogen sulfide alleviates aluminum toxicity in barley seedlings, Plant Soil, 362, 301-318 (2012). https:// doi.org/10.1007/s11104-012-1275-7

Dawood, M., Cao, F., Jahangir, M. M., Zhang, G., $\mathrm{Wu}, \mathrm{F}$., Alleviation of aluminum toxicity by hydrogen sulfide is related to elevated ATPase, and suppressed aluminum uptake and oxidative stress in barley, Journal of hazardous materials, 209210, 121-128 (2012). https://doi.org/10.1016/j. jhazmat.2011.12.076

Fu, P., Wang, W., Hou, L., Liu, X., Hydrogen sulfide is involved in the chilling stress response in Vitis vinifera L., Acta Societatis Botanicorum Poloniae, 82, 295-302 (2013). https://doi.org/10.5586/ asbp.2013.031

Garcia Jr., O., Bigham, J. M., Tuovinen, O.H., Oxidation of isochemical $\mathrm{FeS}_{2}$ (marcasitepyrite) by Acidithiobacillus thiooxidans and Acidithiobacillus ferrooxidans. Minerals Engineering, 20, 98-101 (2007). https://doi. org/10.1016/j.mineng.2006.05.005

Harneit, K., Göksel, A., Kock, D., Klock, J. H., Gehrke, T., Sand, W., Adhesion to metal sulfide surfaces by cells of Acidithiobacillus ferrooxidans, Acidithiobacillus thiooxidans and Leptospirillum ferrooxidans, Hydrometallurgy, 83, 245-254(2006). https://doi.org/10.1016/j.hydromet.2006.03.044

Huang, X., Zalma, R., Pezerat, H., Factors that influence the formation and stability of hydrated ferrous sulfate in coal dusts. Possible relation to the emphysema of coal miners. Chemical research in toxicology, 7, 451-457 (1994). https://doi. org/10.1021/tx00039a025

Jackson, T. A., Evidence for selective adsorption and polymerization of the L-optical isomers of amino acids relative to the D-Optical isomers on the edge faces of kaolinite, Experientia, 27, 242-244 (1970). https://doi.org/10.1007/BF02138119

Johansson, U., Holmgren, A., Forsling, W., Frost, R., Isotopic exchange of kaolinite hydroxyl protons: a diffuse reflectance infrared Fourier transform spectroscopy study, Analyst, 123, 641-645 (1998). https://doi.org/10.1039/a707060h

Kinzler, K., Gehrke, T., Telegdi, J., Sand, W., Bioleaching - a result of interfacial processes caused by extracellular polymeric substances (EPS), Hydrometallurgy, 71, 83-88 (2003). https:// doi.org/10.1016/S0304-386X(03)00176-2
Klein, J., Technological and economic aspects of coal biodesulfurisation, Biodegradation, 9, 293-300 (1998).

Kniess, C. T., Lima, J. C. de, Prates, P. B., The Quantification of Crystalline Phases in Materials: Applications of Rietveld Method, In: Shatokha, D. V. (Ed.), Sintering - Methods and Products. Intech, Brazil (2012).

Kodama, A., Mori, T., Studies on the metabolism of a sulfur-oxidizing bacterium IV. Growth and oxidation of sulfur compounds in Thiobacillus thiooxidans, Plant Cell Physiology, 9, 709-723 (1968).

Lagaly, G., Ogawa, M., Dékány, I., Clay mineral organic interactions, Handbook of Clay Science, 1, 309-377 (2006). https://doi.org/10.1016/S15724352(05)01010-X

Linares-Solano, A., Martín-Gullon, I., SalinasMartínez de Lecea, C., Serrano-Talavera, B., Activated carbons from bituminous coal: effect of mineral matter content, Fuel, 79, 635-643 (2000). https://doi.org/10.1016/S0016-2361(99)00184-2

Liu, J., Wang, Z., Li, B. M., Zhang, Y. H., Interaction between pyrite and cysteine. Transactions of Nonferrous Metals Society of China, 16, 943$946 \quad$ (2006). https://doi.org/10.1016/S10036326(06)60356-7

Lu,L., Sahajwalla, V., Kong, C., Harris, D., Quantitative $\mathrm{X}$-ray diffraction analysis and its application to various coals, Carbon, 39, 1821-1833 (2001). https://doi.org/10.1016/S0008-6223(00)00318-3

Ma, C., Eggleton, R. A., Cation exchange capacity of kaolinite, Clays and Clay Minerals, 47, 174-180 (1999). https://doi.org/10.1346/ CCMN.1999.0470207

Malik, A., Dastidar, M. G., Roychoudhury, P. K., Factors limiting bacterial iron oxidation in biodesulphurization system, Int. J. Miner. Process., 73, 13-21 (2004). https://doi.org/10.1016/j. minpro.2003.07.001

Malik, A., Dastidar, M. G., Roychoudhury, P. K., Biodesulphurization of Coal: Mechanism and Rate Limiting Factors, J. Environ. Sci. Heal. Part A, 36, 1113-1128 (2001). https://doi.org/10.1081/ESE100104135

McCusker, L. B., von Dreele, R. B., Cox, D. E., Loue, D., Scardi, P., Rietveld refinement guidelines, J. Appl. Crystalography, 32, 36-50 (1999). https:// doi.org/10.1107/S0021889898009856

Meruane, G., Oxidación Bacteriana de Sulfato Ferroso, Ph.D. Thesis, Universidad de Chile (2002).

Nemati, M., Harrison, S. T. L., Hansford, G. S., Webb, C., Biological oxidation of ferrous sulphate by Thiobacillus ferrooxidans: a review on the kinetic aspects. Biochemical Engineering Journal, 1, 171-190 (1998). https://doi.org/10.1016/S1369703X(98)00006-0 
Panda, A. K., Mishra, B. G., Mishra, D. K., Singh, R. K., Effect of sulphuric acid treatment on the physico-chemical characteristics of kaolin clay, Colloids Surfaces A: Physicochemical and Engineering Aspects, 363, 98-104 (2010). https:// doi.org/10.1016/j.colsurfa.2010.04.022

Pandey, R. A., Raman, V. K., Bodkhe, S. Y., Handa, B. K., Bal, A. S., Microbial desulphurization of coal containing pyritic sulphur in a continuously operated bench scale coal slurry reactor, Fuel, 84, 81-87 (2005). https://doi.org/10.1016/j. fuel.2004.07.011

Petrović, M. B., Radovanović, M. B., Simonović, A. T., Milić, S. M., The Effect of Cysteine on the Behaviour of Copper in Neutral and Alkaline Sulphate Solutions, International Journal of Electrochemical Science, 7, $9043-9057$ (2012). https://doi.org/10.2478/s11696-012-0174-y

Rawlings, D. E., Characteristics and adaptability of iron-and sulfur-oxidizing microorganisms used for the recovery of metals from minerals and their concentrates, Microbial Cell Factories, 15, 1-15 (2005).

Rohwerder, T., Sand, W., The sulfane sulfur of persulfides is the actual substrate of the sulfuroxidizing enzymes from Acidithiobacillus and Acidiphilium spp. Microbiology, 149, 1699-1710 (2003). https://doi.org/10.1099/mic.0.26212-0

Rojas-Chapana, J., Tributsch, H., Biochemistry of sulfur extraction in bio-corrosion of pyrite by Thiobacillus ferrooxidans, Hydrometallurgy, 59, 291-300 (2001). https://doi.org/10.1016/S0304386X(00)00185-7

Rojas-Chapana, J.A., Tributsch, H., Bio-leaching of pyrite accelerated by cysteine, Process Biochemistry, 35, 815-824 (2000). https://doi. org/10.1016/S0032-9592(99)00142-9

Ryu, H. W., Chang, Y. K., Kim, S. D., Microbial coal desulfurization in an airlift bioreactor by sulfuroxidizing bacterium Thiobacillus ferrooxidans, Fuel Processing Technology, 36, 267-275 (1993). https://doi.org/10.1016/0378-3820(93)90036-4

Salari, H., Mozafari, H., Torkzadeh, M., Moghtader, M., Pyrite oxidation by using Thiobacillus ferrooxidans and Thiobacillus thiooxidans in pure and mixed cultures, Biological Diversity and Conservation, 1, 115-123 (2008).

Sand, W., Gehrke, T., Extracellular polymeric substances mediate bioleaching/biocorrosion via interfacial processes involving iron(III) ions and acidophilic bacteria, Research in Microbiology, 157, 49-56 (2006). https://doi.org/10.1016/j. resmic. 2005.07 .012

Sand, W., Gehrke, T., Jozsa, P. G., Schippers, A., (Bio) chemistry of bacterial leaching - direct vs. indirect bioleaching, Hydrometallurgy, 59, 159-175 (2001). https://doi.org/10.1016/S0304-386X(00)00180-8

Schippers, A., Sand, W., Bacterial Leaching of Metal Sulfides Proceeds by Two Indirect Mechanisms via Thiosulfate or via Polysulfides and Sulfur, Applied and Environmental Microbiology, 65, 319-321 (1999).

Simanjuntak, W., Sembiring, S., The use of the Rietveld method to study the phase composition of cordierite $\left(\mathrm{Mg}_{2} \mathrm{Al}_{4} \mathrm{Si}_{5} \mathrm{O}_{18}\right)$ ceramics prepared from rice husk silica, Makara, Sains, 15, 97-100 (2011).

Teng, H., Yeh, T.-S., Hsu, L.-Y., Preparation of activated carbon from bituminous coal with phosporic acid activation, Carbon, 36, 1387-1395 (1998). https:// doi.org/10.1016/S0008-6223(98)00127-4

Theng, B. K. G., Proteins and Enzymes, Developments in Clay Science, 4, 245-318 (2012). https://doi. org/10.1016/B978-0-444-53354-8.00008-6

Travisany, D., Cortés, M. P., Latorre, M., Di Genova, A., Budinich, M., Bobadilla-Fazzini, R. A., Parada, P., González, M., Maass, A., A new genome of Acidithiobacillus thiooxidans provides insights into adaptation to a bioleaching environment, Research in Microbiology, 1-9 (2014). https://doi. org/10.1016/j.resmic.2014.08.004

Tributsch, H., Direct versus indirect Bioleaching, Hydrometallurgy, 59, 51-60 (2001). https://doi. org/10.1016/S1572-4409(99)80005-4

Tuovinen, O. H., Kelly, D. P., Studies on Growth of Thiobacillus ferrooxidans. I. Use of membrane filters and ferrous iron agar to determine viable numbers, and comparison with ${ }^{14} \mathrm{CO}_{2}$-Fixation and Iron Oxidation as Measures of Growth, Archiv für Mikrobiologie, 88, 285-298 (1973). https://doi. org/10.1007/BF00409941

Wang, Z., Xie, X., Xiao, S., Liu, J., Comparative study of interaction between pyrite and cysteine by thermogravimetric and electrochemical techniques, Hydrometallurgy, 101, 88-92 (2010). https://doi. org/10.1016/j.hydromet.2009.11.015

Wood, J. L., Biochemical functions of persulphides, Advances in Experimental Medicine and Biology, 148, 327-342 (1982). https://doi.org/10.1007/978$1-4615-9281-5 \_26$ 